\title{
IMPACT OF FINANCIAL RISK MANAGEMENT MEASURES ON FINANCIAL PERFORMANCE OF A BANK - CASE OF AXIS BANK
}

\author{
*Ms. Kiran Hiremath
}

\begin{abstract}
:
Banking industry occupies strategically key position in an economy as they are the key enabler for rest of the industries. Efficient banking industry can create conducive economic environment in which other manufacturing and service sector thrive. Commercial banks are like any other commercial venture in terms that it aims to earn profit but they are unique as they deal in money. Bank as a business entity operating in the vibrant globalized economy faces many challenges. These challenges can be termed as risks as they have fair amount of knowledge about them. In fact, economy health can be assessed by understanding financial performance of the banks (Haque, Sharma, 2011). Bank's financial performance can be assessed by return on asset (ROA) and return on equity (ROE). As per Bank for International settlement banking activities are related to customers and investment of equity. This gives rise to financial risk. There is inverse relationship between risk and return. Banks must balance its exposure to financial risk and the returns earned. Efficient financial risk management should have favourable impact on the profitability of the bank. In this paper a case of Axis bank is considered to understand the association between the financial risk management and the returns earned by the bank. It is found that efficient risk management has impact on the performance of the bank.
\end{abstract}

Key words: Financial risk, Return on Asset, Credit Risk, Liquidity Risk, Foreign Exchange Risk

JEL Code: $G 21$, G32

\section{Introduction}

Every business organization faces risk. Risk in general terms means the adverse or undesirable situation. In today's dynamic and global business environment all business entities face risk and the firm which manages the risks in the most efficient manners also ends up earning optimum profits. Most of the ITES sector companies has appointed Risk Officer, whose primary job is to watch the changes in the business environment and its impact on the firm. Commercial banks are in the business organization who deal in money. It is imperative that banks who deal in other's money, need to practice prudent risk management practices as they have obligation to return deposit at appropriate time and they also have obligation to create value for its shareholders.

All the banks should manage financial risk

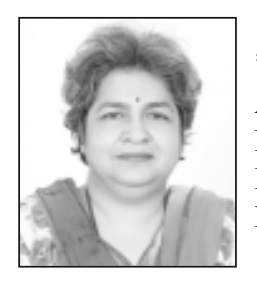

*Ms. Kiran Hiremath

Assistant Professor

Dayananda Sagar College of Arts, Science \& Commerce

Email : kiranghiremath@gmail.com

Mobile No. : +91 9886335383 
efficiently to get optimum return. In 1994, Reserve Bank of India allowed private players to enter the banking sector. Before entry of private sector banks, commercial banking space was dominated by public sector banks. The main objective to open doors for private sector banks was to introduce competition and to get FDI in this sector. Along with FDI these banks were also expected to bring in state of art technology along with innovative services to the customers and cater to growing demand for the banking services. Axis Bank is a new generation bank floated by Unit Trust of India, Life Insurance corporation of India, General Corporation of India, National Insurance Company Ltd., The New India Assurance company Ltd., The Oriental Insurance Company Ltd. and United, India Insurance Company Ltd. in 1993. The bank started its operations in 1994. Being private sector bank, wealth maximization is the objective of the bank. Axis Bank has achieved five years (201011 to 2015-16) CAGR of $17 \%$. On the asset quality front also it has done well by registering growth in Total Assets, Total Deposits, Total Advances and Net profit by $17 \%, 14 \%, 19 \%$ and $19 \%$ respectively. Case of Axis bank is considered to understand financial risk management and its impact on the profitability of the company.

Financial risk management is the quality control of finance. It is a broad term used in different senses for different businesses or things but basically it involves identification, analyzing, and taking measures to reduce or eliminate the exposures to loss by an organization or individual (Muteti, 2014)

Financial risk has five components, namely credit risk, interest rate risk, foreign exchange risk, capital management risk and liquidity risk.

\section{Literature Review}

Muteti (2014) The author has collected data from Central Bank of Kenya and Commercial Banks to analyse the relationship between financial risk and financial performance of banks.

To analyse the data multiple regression model is used. The study revealed that there was a negative association between default risk, risk due to fluctuations in interest rate, foreign exchange risk, liquidity risk and profitability of commercial banks in Kenya. The study also revealed that there was a positive relationship between capital management risk, bank deposits, bank size and profitability of commercial banks in Kenya. The study recommends that commercial bank should control their default risk, through nonperforming loan level as it negatively affects the financial performance of commercial banks in Kenya. The commercial banks in Kenya should maintain the liquidity at safe level as it was found that liquidity risk negatively affect the financial performance of commercial banks in Kenya. The management of commercial banks in Kenya should hedge against foreign exchange risk and interest rate risk as it has negative impact on the profitability of commercial bank in Kenya. The author recommends that there is need for commercial banks in Kenya to increase their size, capital, risk management and also their bank deposits.

Goyal and Kaur (2008) in the study conducted by them has considered seven new private sector banks to analyse their performance by using descriptive statistical tools, CAGR, and one-way ANOVA. Besides these statistical tools, appropriate ratios relating to capital adequacy, asset quality, employee productivity, earning quality and liquidity of banks were calculated. All the banks considered for the study have favourable 
capital adequacy ratio - $9 \%$ above the prescribed limit of Reserve Bank of India. In case of Kotak Mahindra Bank, increase in the NPA has been the highest. Axis bank has the maximum debt/equity ratio among the banks considered for the study. All the banks have performed well in lending operations as advances to total assets ratio has shown an increasing trend for all the banks under study. Mean ratios of all the parameters considered for the study shows significant differences among the mean ratios of all parameters except for liquid assets to total assets, liquid assets to total deposits, net profit to average assets and percentage change in NPAs.

Arora and Kaur (2008) have grouped the banks on the basis of nationalization, SBI group, new private sector banks and foreign banks to study the profitability of banks in India.The data is collected for the period 200005 . To evaluate the financial performance of the banks, Profitability ratios like return on assets, interest income to total income, noninterest income to total income and capital ratios have been computed. To assess the association between interest income and noninterest income among different bank groups, correlation coefficient has also been used. The analysis of data shows that banks have experienced continuous decline in interest margin. The study has also found out that bank's income from alternative sources has increased over the years. Public sector banks income has interest as the primary source of income while private sector and foreign banks have non-traditional sources as primary source of income.

Rajkumar (2007) the author has considered financial statements, 28 Private Sector Banks for the period of 2004-06, to analyse their performance. The data related to income, expenditure and profits were collected from the financial statements. The ratios related to interest, expenditure, income and operating profit were calculated to evaluate the performance. The study found that there was more increase in interest income in the year 2005-06 as compared to 2004- 05, but operating expenses among total expenditure showed decline. All 28 Private Sector Banks' profitability ratios showed increasing trend. Based on the amount of profit earned, during the period of study, ICICI Bank was ranked No. 1 followed by HDFC Bank, UTI Bank and Federal Bank. At the same time Development Credit Bank Ltd. and United Western Bank Ltd incurred losses.

Singh and Kohli (2006) have studied 30 Private Sector Banks to evaluate their performance based on the CAMEL model. For the study data for the period 2003-2005 was collected. Based on ratios, ranks have been assigned to individual banks and composite scores have been calculated. We have used SWOT to know the strengths and weakness of the bank. Bank of Punjab has scored the highest points followed by HDFC Bank and Jammu \& Kashmir Bank. On the other hand, ING Vysya Bank, South Indian Bank and Lord Krishna Bank scored the least composite ranks. Based on the study, author states the finding that the banks performing well have innovative new products, utilize of manpower resource inefficient manner and have strong brands. The study also pointed out that the public sector banks were facing stiff competition from foreign banks. The author suggests that public sector banks can compete against foreign sector banks by providing efficient services. These banks should also be proactive in assessing the present competitive environment and develop effective strategies to face them.

Sharma (2006) has considered all the banks operating in the state of Haryana. It 
includes public sector, private sector and regional rural Banks. Performance of Punjab National Bank is compared with rest of the banks. For the study data have been collected for the period of ten years $(1993$ - 2004). It is a comparative study, and performance of Punjab National Bank in agricultural and nonagricultural sector is compared to rest of the banks. Statistical tools such as mean, coefficient of correlation, standard deviation, growth rate and trend analysis has been used to analyse the secondary data collected for the study.Based on the analysis it is found that Punjab National Bank has highest growth in non-agricultural sector advances whereas minimum growth rate in agricultural advances. It was found that Punjab National Bank has introduced fee based services to meet the needs of Haryana's economy which was growing at the accelerated growth rate and to improve bank's profitability. Based on the study author suggests that the banks should improve its communication system and customer relationship in rural market and develop suitable marketing strategies for the rural market.

Maji and Day (2006) have considered public sector and private sector banks to study productivity and profitability of the banks in India. For the study five each banks from public sector and private sector have been selected based on the deposit mobilization. Data for the study have been collected for the period of $1996-2003$. Productivity index was calculated for all the banks selected for the study. It was found that almost all the banks had productivity index greater than one. Based on the analysis of the data it was found that of State Bank of India and Punjab National Bank were ranked highest in profitability and Jammu \& Kashmir Bank, Canara Bank and Bank of India were ranked low. It was found that the primary factor influencing the profitability was the Interest spread. The authors conclude the study by suggesting that Bank of India and Jammu Kashmir Bank should develop appropriate strategies to improve the profitability of the Bank.

Debasish (2006) has divided banks based on bank size, ownership pattern and years of operation to study the performance of Indian Banks. Data for the study has been collected for the period of $1997-2004$. Based on the study, the author has found out that Foreign Banks are more efficient as compared to public sector banks and private sector banks. Further the author states that at local level large size banks are more efficient than the small and medium size banks. But at global level it is the small size banks found to be more efficient than the medium size banks. When comparison is made between new and old private sector banks, new private sector banks are more efficient as old private sector banks were burdened with old debts.

\section{Objectives}

The study has been undertaken to understand the association between various components of financial risk management and bank performance. In this study, the components of financial risk considered are credit risk, interest rate risk, foreign exchange risk, capital management risk and liquidity risk. Bank size is also considered to capture the effect of bank size on profitability. Bank performance is measured by return on equity and return on assets. In view, the following hypothesis have been formulated and tested.

\section{Hypotheses}

H01: There is no relationship between performance of bank as criterion variable and financial risk management as predictor variables. 


\section{Research Design}

Descriptive and analytical research design is adopted for the present study. The data for the study has been collected from the secondary sources, namely annual reports of Axis bank, for the duration of ten years (20072016).Multi regression model is used to arrive at the empirical results with bank performance as criterion variable and financial risk management factors as predictor variables.

\section{Model}

The empirical model used in the study is to test the impact of financial risk management on financial performance of Axis bank.

$\mathrm{Y}=\alpha+\beta 1 \mathrm{X} 1+\beta 2 \mathrm{X} 2+\beta 3 \mathrm{X} 3+\beta 4 \mathrm{X} 4+\beta 5 \mathrm{X} 5+\beta 6 \mathrm{X} 6$

$+\beta 7 \mathrm{X} 7+\varepsilon$

\section{Where:}

Y: Return on assets (ROA) and return on equity (ROE) as measure of performance.

X1: Credit risk, which was measured by using the level of non-performing asset to total loans and advances.

X2: Interest rate risk, which was measured by using the ratio of the interest rate sensitivitygap between assets and liabilities maturity within a period less or equal to 1 year to total assets.

X3: Foreign exchange risk, which was measured by using the ratio of net foreign currency exposure between assets and liabilities to total assets.

X4: Liquidity risk, which was measured by using total loans to total deposit.

X5: Capital management risk, which was measured by using the ratio of capital and reserveto total assets.

X6: Bank's deposits, which was measured by using the ratio of deposits to total assets.
X7: Bank's size, which was measured by using natural $\log$ of total deposits. The size of the bank has impact on the economies of scale.

\section{Operational definitions}

Credit risk - Banks accept deposits and lends money to the borrowers. The bank's profitability depends on the payment of interest on the amount borrowed and return of principal amount. For this purpose, banks carry out financial soundness analysis, this analysis is called credit risk analysis. Greuning and Bratanovic (2009) define credit risk as the chance that a debtor or issuer of a financial instrument whether an individual, a company, or a country will not repay principal and other investment-related cash flows according to the terms specified in a credit agreement. Credit risk means that the payment may be delayed and this affects bank's cash flow.

Interest Rate Risk - Banks pay interest on the deposit received and receive interest on the amount given out as loan. The difference between these interest rate is margin earned by the bank. Interest rate can fluctuate over a period of time. Of course banks can also revise the interest rate for the deposits and for loans to earn its margin. This revision in interest rate to protect the profit margin is possible if banks assets and liabilities match in duration. In case it does not match then there is chance that it might have adverse impact on the margin and in turn on the profitability of the bank.

Foreign Exchange Risk - banks need to face this risk if it is engaged in international business. The bank's profit margin gets affected by the variation in the exchange rate. It is difficult to predict the variation in exchange rate. The bank can measure this risk by calculation transaction exposure.

Capital Management Risk - bank's capital can be calculated by subtracting its liabilities 
from the assets. Banks liabilities include customer deposits and money borrowed from other banks. Assets incudes cash, loans to the customers and securities. Banks need to maintain capital structure as per the Basel regulations. As per Basel regulations, capital is divided into Tier-1 capital and Tier-2 capital. Tier-1 capital includes shareholder's equity and retained earnings. Tier-2 capital includes revaluation reserve, subordinated term loans, hybrid capital instruments and undisclosed reserves. Banks having large capital as compared to its liabilities is in good position and is not susceptible to bankruptcy in case of financial losses.

Liquidity Risk - liquidity means the ability of banks to meet its cash or near cash obligations without sustaining loss. Liquidity risk means banks inability to meet cash or short term financial demands without sustaining loss. In other words it also means bank is able to raise the required funds without incurring unreasonable cost. Banks may face liquidity risk if duration of loans advanced and the duration of deposit maturity does not match.

Return on Asset (ROA) : This ratio is calculated to measure the net income to total assets of the company.

$\mathrm{ROA}=($ Net Income $/$ Total Assets $) * 100$

Return on Equity (ROE): This ratio is calculated to measure the annual net income to shareholder's equity of the company

ROE $=$ (Annual Net Income / Shareholder's Equity)*100

\section{Results and discussions}

\section{(A) Regression for ROA}

Table 1

\begin{tabular}{|l|l|l|l|l|l|}
\hline Model & $\mathrm{R}$ & R Square & $\begin{array}{l}\text { Adjusted R } \\
\text { Square }\end{array}$ & $\begin{array}{l}\text { Std. Error of } \\
\text { the Estimate }\end{array}$ & $\begin{array}{l}\text { Durbin } \\
\text { Watson }\end{array}$ \\
\hline 1 & $.996^{\mathrm{a}}$ & .991 & .960 & .04409 & 1.945 \\
\hline
\end{tabular}

The above table shows the detail about regression model, through ENTER model which tell us the value of the company's depended significantly. This table shows that ' $R$ ' $(99.6 \%)$ is the correlation coefficient which is found to be very high between the dependent variable and predictor variable, ' $\mathrm{R}^{2}$ ( $\left.99 \%\right)$ is high and suggest change in the dependent variable explained by independent variable which is significantly a good model. Adjusted $\mathrm{R}$ square is a coefficient which tells us about the variation in the dependent variable due to change in independent variable. Adjusted $\mathrm{R}$ square was (96\%) which indicate the financial performance of Axis bank due to change in credit risk, interest rate risk, foreign exchange risk, liquidity risk, capital management risk, bank deposits and bank size. The model has Durbin-Watson value of 1.9, which is near to 2. This value of Durbin-Watson indicates there is no autocorrelation in the sample.

Table 2 - ANOVA

\begin{tabular}{|ll|l|l|l|l|l|}
\hline \multicolumn{1}{|c|}{ Model } & $\begin{array}{l}\text { Sum of } \\
\text { Squares }\end{array}$ & df & $\begin{array}{l}\text { Mean } \\
\text { Square }\end{array}$ & F & Sig. \\
\hline \multirow{2}{*}{1} & Regression & .431 & 7 & .062 & 31.682 & $.031^{\mathrm{b}}$ \\
& Residual & .004 & 2 & .002 & & \\
& Total & .435 & 9 & & & \\
\hline
\end{tabular}


Table 3 reveals the details pertaining to ANOVA of the bank performance as measured by return on assets. Since significance of ' $F$ ' is less than 0.05 , we reject the null hypothesis. This shows that the overall model was significantly influencing the financial performance of Axis bank. Therefore, at $5 \%$ significance level null hypothesis is rejected and alternate hypothesis is accepted. Hence it can be concluded that bank profitability is dependent on financial risk management factors.

Table 3 - Coefficients ${ }^{\mathrm{a}}$

\begin{tabular}{|c|c|c|c|c|c|c|}
\hline \multicolumn{2}{|c|}{ Model } & \multicolumn{2}{|c|}{$\begin{array}{l}\text { Unstandardized } \\
\text { Coefficients }\end{array}$} & \multirow{2}{*}{$\begin{array}{l}\text { Standardized } \\
\text { Coefficients } \\
\text { Beta } \\
\end{array}$} & \multirow[t]{2}{*}{$\mathrm{t}$} & \multirow[t]{2}{*}{ Sig. } \\
\hline & & $\mathrm{B}$ & Std. Error & & & \\
\hline \multirow{8}{*}{1} & (Constant) & -9.354 & 3.598 & & 2.600 & .122 \\
\hline & $\mathrm{X} 1$ & -.232 & .473 & -.311 & -.491 & .672 \\
\hline & $\mathrm{X} 2$ & .025 & .016 & .432 & 1.590 & .253 \\
\hline & $\mathrm{X} 3$ & -.065 & .026 & -.367 & -2.482 & .131 \\
\hline & $\mathrm{X} 4$ & .005 & .003 & .611 & 1.788 & .216 \\
\hline & $\mathrm{X} 5$ & -.066 & .039 & -.512 & -1.677 & .236 \\
\hline & $\mathrm{X} 6$ & .016 & .010 & .322 & 1.541 & .263 \\
\hline & $\mathrm{X} 7$ & 1.925 & .735 & 2.418 & 2.617 & .120 \\
\hline
\end{tabular}

From the above data shown in coefficient table, the regression equation was

$\mathrm{Y}=-9.354-0.232 \mathrm{X} 1+0.025 \mathrm{X} 2-0.065 \mathrm{X} 3+0.005 \mathrm{X} 4-0.066 \mathrm{X} 5+0.16 \mathrm{X} 6+1.925 \mathrm{X} 7$

From the above regression equation reveals beta coefficient for credit risk, foreign exchange ratio and capital management risk has negative sign, indicating negative correlation with bank performance.

\section{(B) Regression for ROE:}

The analysis and the interpretation has been done in order to test the impact of all predictor variables taken from Axis bank. In this model, ROE is dependent variable.

Table - 4 Model Summary

\begin{tabular}{|l|l|l|l|l|l|}
\hline Model & $\mathrm{R}$ & R Square & $\begin{array}{l}\text { Adjusted R } \\
\text { Square }\end{array}$ & $\begin{array}{l}\text { Std. Error of } \\
\text { the Estimate }\end{array}$ & $\begin{array}{l}\text { Durbin - } \\
\text { Watson }\end{array}$ \\
\hline$\dot{1} 1$ & $.986^{\mathrm{a}}$ & .972 & .872 & .8030 & 2.000 \\
\hline
\end{tabular}

The above table shows the detail about regression model, through ENTER model which tell us the value of the company's depended significantly. This table shows that ' $R$ ' $(98.6 \%)$ is the correlation coefficient which is found to be very high between the dependent variable and predictor variable, 
'R2' (97\%) is found to be reasonably high and suggest change in the dependent variable explained by independent variable which is significantly good model. Adjusted R square is a coefficient which tells us about the variation in the dependent variable due to change in independent variable. Adjusted R square was (87\%) which indicate the financial performance of Axis bank due to change in credit risk, interest rate risk, foreign exchange risk, liquidity risk, capital management risk, bank deposits and bank size at $97 \%$ confidence interval.

Table 5 - ANOVA

\begin{tabular}{|cl|l|c|l|l|l|}
\hline \multicolumn{2}{|c|}{ Model } & $\begin{array}{l}\text { Sum of } \\
\text { Squares }\end{array}$ & df & $\begin{array}{l}\text { Mean } \\
\text { Square }\end{array}$ & F & Sig. \\
\hline 1 & Regression & 44.058 & 7 & 6.294 & 9.761 & $.096^{\mathrm{b}}$ \\
& $\begin{array}{l}\text { Residual } \\
\text { Total }\end{array}$ & 1.290 & 2 & .645 & & \\
& 45.348 & 9 & & & \\
\hline
\end{tabular}

Table 5 reveals the details pertaining to ANOVA performance of bank measured by return on equity. Since Sig. ' $F$ ' is greater than 0.05 , we accept the null hypothesis and conclude that bank performance does not depend on the financial risk factors.

Table 6 - Coefficients

\begin{tabular}{|l|l|l|l|l|l|}
\hline Model & \multicolumn{2}{|l|}{$\begin{array}{l}\text { Unstandardized } \\
\text { Coefficients }\end{array}$} & $\begin{array}{l}\text { Standardized } \\
\text { Coefficients }\end{array}$ & $\mathrm{t}$ & Sig. \\
\hline & B & Std. Error & Beta & & \\
(Constant) & -61.803 & 65.526 & & -.943 & .445 \\
X1 & 3.041 & 8.617 & .399 & .353 & .758 \\
X2 & .330 & .290 & .553 & 1.141 & .372 \\
X3 & -1.043 & .479 & -.575 & -2.176 & .161 \\
X4 & .039 & .052 & .454 & .744 & .534 \\
X5 & -2.568 & .719 & -1.944 & -3.572 & .070 \\
X6 & .295 & .187 & .586 & 1.571 & .257 \\
X7 & 13.542 & 13.396 & 1.666 & 1.011 & .418 \\
\hline
\end{tabular}

From the above data shown in coefficient table, the regression equation for ROE was

$\mathrm{Y}=-61.803+3.041 \mathrm{X} 1+0.330 \mathrm{X} 2-1.043 \mathrm{X} 3+0.039 \mathrm{X} 4-2.568 \mathrm{X} 5+.0295 \mathrm{X} 6+13.542 \mathrm{X} 7$

From the above regression equation, it is clear that credit risk, interest rate risk, foreign exchange risk, liquidity risk, capital management risk, bank deposits and bank size have least impact on the performance of the bank. 


\section{Conclusion}

Financial risk management ensures that not only bank stays solvent but also creates value for its equity shareholders. The data is analysed using regression model using ROA and ROE as criterion variable. The model summary of both analysis shows that it is good model as $\mathrm{R}$ square for the regression equations is $99 \%$ and $87 \%$ for regression for ROA and ROE respectively. Based on ANOVA analysis we find that regression model for ROA is significant at 5\%. Regression model with ROA seems to be appropriate model for banks as banks primary assets are the loans disbursed to its customers and its efficient management has direct impact on the banks profitability. The constant value is negative showing that there is negative correlation between risk and the return earned by the banks. Hence we can conclude that banks having good strategies to manage financial risk would earn optimum profit.

\section{References:}

- Arora S, Kaur S. (2008). Diversification in Banking Sector in India Determinants of Financial Performance. Indian Journal of Commerce, Vol.61, No.3, pp.13-21.

- Bank for International Settlement. Risk Management. Retrieved from https://www.bis.org/about/risk_manageme nt.htm

- Debasish, S.S. (2006), "Efficiency Performance in Indian Banking: Use of Data Envelopment Analysis", Global Business Review, Issue-7, pp 325333.Available at: www.gbr.sagepub.com

- Dhanini, F. (2007), "Fear is the Key: A Behavioral Guide to Underwriting Cycles", vol. 10 Connecticut Insurance Law Journal 255.
- Empirical Study of Banks in Europe, 2005-2010; Umea School of Business.

- Goyal R. Kaur R. (2008). Performance of New Private Sector Banks in India. The Indian Journal of Commerce. Vol. 61, No. 3, July September, pp.1-11

- $\quad$ Greuning, Hennie van \& Bratanovic, Sonja Brajovic. (2009), 'Analyzing Banking Risk: A Framework for Assessing Corporate Governance and Risk Management' 3 rd Edition. The World Bank. Washington, USA.

- Haque, MD Imdadul and Raj Bahadur Sharman (2011) Benchmarking Financial Performance of Saudi Banks Using Regression. IJBEMR Vol. 2, Issue 1, pp:78-84.

- Maji, G.S.; and Day, S. (2006), "Productivity and Profitability of Select Public Sector Banks in India: An Empirical Analysis", The ICFAI Journal of Bank Management, Vol. V, No. 4, pp. 59-67

- MutetiS R. (2014). Relationship Between Financial Risk Management and Financial Performance of Commercial Banks in Kenya.

D63/79121/2012.https://scholar.google.co. in/scholar?hl=en\&as_sdt $=0 \% 2 \mathrm{C} 5 \&$ sciodt $=$ $0 \% 2 \mathrm{C} 5 \&$ cites $=13496347876507377574 \&$ scipsc $=\& q=S A M M Y+$ RAYMOND + MUT $\mathrm{ETI} \& b \operatorname{tnG}=$

- Narmadha M, Jagdeesan J, Lalithakumari G, SelvakumarJ, (2016), Understand Role of Private Sector Banks in India, IJARMATE,

- Rajkumar P.K. (2007). The Earning Performance of Private Sector Banks 
During 2005-06. The Journal of Accounting and Finance, Vol.21, No. 2, April-September

- Sharma, N. (2006), "Performance of Punjab National Bank in Competitive Environment. A case study of Haryana", A Doctoral Thesis submitted to Punjabi University, Patiala.

- Singh D, Kohli, G. (2006). Evaluation of Private Sector Banks in India - A SWOT Analysis. Journal of Management
Research, Vol.6, No. 2, August, pp. 84101.

- Tandon S, Choudhary V. (2010). Total Factor Productivity of Public Sector Banks in India: A Malmquist Approach. Gyanpratha, ACCMAN Journal of Management, Vol 2 (Issue 1), pp. 81-90, January 2010 ISSN: 0975-0584.

- Toutou J. (2011). The Relationship between Liquidity Risk and Performance, An 43 